\title{
PAPERS PRESENTED AT THE 7th EUROPEAN CONFERENCE ON EARTHQUAKE ENGINEERING, ATHENS, SEPT. 20-25, 1982.
}

\section{LIST OF PAPERS}

SESSION 1.: POSSIBLE TRENDS IN HARMONIZATION OF EUROPEAN COUNTRIES CODES AND COORDINATION OF THE RESEARCH WORK

. On an equivalent lateral-force procedure suitable for codes

Riko Rosman

2. New Romanian code for the aseismic design of miltistory building shear-wall structures R. Agent, T. Postelnicu, D. Constantinescu M. Barbaiani

3. A comparative study of the earthquake resistance regulations of non-European countries H. Demir, Z. Polat

4. Some problems concerning elaboration of building codes for seismic regions S.V. Polyakov, F.V. Bobrov, V.I. Oiserman

5. On formalization of qualification system for earthquake engineering

Yu K. Krasikov A.M. Paramzin

6. Regional model code for seismic design based on probabilistic conceptions

S. Sachanski, H. Shah, P. Carydis, G. Serbanescu,

N. Bayülke, D. Petrovski

SESSION 2.: STRONG GROUND MOTIONS AND FOUNDATION ENGINEERING

SESSION 2.1.: SEISMICITY

1. Acceleration distribution analysis of Montenegro earthquake of April, 15, 1979

D. Petrovski, J. Petrovski, N. Naumovski, S. Stamatovska

2. Location of the seismogene origin of El Asnam (Algeria) in the Northern atlas area M. Arsovski, J. Jancevski

3. The asymptotical method for seismic risk estimation V.A. Nechaev

4. The correlation of the Japan meteorological agency intensity scale with physical parameters of strong gound motions

S. Midorikawa

5. On the hazard of artace rupture in the seismic active zones of the Mediturraneen region

D. Papastamatiou

6. On the corralection of MM intensity with parametere of ground shaking

C.F. Aptikaev

7. Approximetion method of expent interval evaluation of earthquake Mmax

V.I. Bune, V.G. Gitis, V.N. Kalenik, M.A. Mironov, J.K. Shchukin

8. Atudy of etrong aerthquakes and prodiction of hazard in Armonis

B. K. Karapetian, N.K. Karapetian, S.A. Pirusian. S.S. Simonian

9. Statistical analysia of ground motion parametera in epicentral areas of strong sarthquakea V.M. Ljatkher, N.I. Frolova

10. Seismic hazard atudie - Data, maps and releted problems V. Mihailov

11. Macrozonstion and wismic riak maps So Gu Kim

12. A minimum stress low model for large earthquakes Anne S. Kiremidjian

13. The seismic surface waves in producing the seimic offect

S.A. Fedorov, O.S. Mirkotan

14. Seismotectonic charecteriatice and their influence on seismic hazard

R. Petkovski, B. Koceva, V. Mihailov

15. Dovelopm in errequake enginesring resesrch in Now Zosiand R.G. Tyler

16. An aftershock survey of the epicentral region of the gutf of Corinth esrthquake of February 24, 1981 N.R. Tilford, J. Drakopoulos, D. Amick, U. Chandra

17. Micrazoning studies and damages from the recent erthquakes in Lourted region G. Leventakis, A. Rousso
SESSION 2.2.: STRONG GROUND MOTIONS

1. A semi-empirical method for estimating response spectra of mear-field ground motions with regard to fault rupture

H. Kobayashi, S. Miodorikawa

2. On the correlation between $X Y Z$-components of earthquake accelerations

R.J. Scherer, G.I. Schuëller

3. A mobile array for digital recording and interpretation of local earthquakes - a prerequisite for the predictio of strong aftershocks M. Steinwachs

4. Stochastic models of spatial ground motions H. Sandi - ROMANIA

5. Complete analysis of the May 17, 1976, Gazl earthquake V.M. Graize

6. Optimization problems of the engineering seismometric stations network V.M. Dorofeev, B.E. Denisov

7. Peak particle ground motions in earthquake near-field V. Schenk

8. An analytical study of the attenuation of earthquake ground motions Jamshid Mohammadi

9. Some problems related to determination of released energy intensity and assessment of seismic ground motion S. Galbov

10. Ground motion during nearby earthquakes I.V. Shteinberg, T.G. Ivanova, O.N. Ponomareva

11. Seismic signal modelling K. Ishtev, Ph. Philipov

12. A methodology for the assessment of ground motion parameters for nuclear power plants P. Gülkan, M. Öner, M. Erdik, MS. Yücemen

13. Dense instrument array program of the Public Works Research Institute and preliminary anslysis of the records

T. Okubo, T. Iwasaki, K. Kawashima

14. Design of strong motion instruments, networks and arrays D.E. Hudson

15. Statistical characterizetion of strong ground motions using the Kanai-Tajimi PSD function Shih-Sheng Paul Lai

16. Earthquake accolerogram destructivenese potentisl foctor R. Araya, G.R. Saragoni

17. Automatic digitization of strong mosion records with linescan camera

G. Georgiev, D. Mutafov

SESSION 2.3.: DYNAMIC PROPERTIES OF SOILS

1. Evaluation of dynamic soil propertisa for geotechnical esrthquake engineering purposes H. Dezfulian N.D. Marach

2. The influance of radietion demping on the seismic response of soil deposits

Dr. E. Mardiross

3. Application of the rendom decrement technique in the determination of damping of soils M.S. Aggour. J.C.S. Yang, H. Al-Sanad

4. A study on comparison of empirically and insitu determined dynamic soil properties H.T. Durgunoglu, S.S. Tezcan, Y.B. Aca

5. Rate dependent dynamic behaviour of a normally consolidsted clay A.M. Ansal, A. Erken

6. Determination of dynamic soll properties in the field A. Bodare, R. Massarsch

7. Experimental down-hole seismic velocity measurement for determination poisson's retio: tochnique and results A. Velev, S. Rangelov

8. On calculating the dynamic-stiffiness metrix of the unbounded soil by cloning J.P. Wolf, B. Weber
SESSION 2.4: SITE EFECTS

Effective stess analysis of a soil layer subjected to osrthquake loading

S.K. Sarma. C.P. Tsatsanifos

2. Site effects on the spectrol shspes of power spectral densities

F.K. Chang

3. Dynamic soil reactions under vertical vibrations in radially non-homogenous soil layer N. Ladshmanan, R. Minai

4. Seismic microzoning map in urban area with regard to fault rupture and site subsurface structure H. Kobayashi, S. Midorikawa

5. Nonlinear seismic response of soft soil-deposits Toshio Iwasaki, K. Kawashima, F. Tatsuoka

6. A study to determine the feasibility of designing and constructing buildings on faults

Michael Yachnis

7. Reduction of the soil amplification effect $H$. Boncheva, L. Tzenov

8. A finite element analysis of soil consolidation unde earthquake conditions R.W. Lewis, K.H. Leung

9. Evaluation of bedrock acceleration based on accelerogram records obiained on soil surface T. Paskalov, Z. Milutinovic

10. Earthquake induced settlements of foundations on clays

S. Tsotsos, K. Pitilakis, Th. Hatzigogos

11. Ground motion in alluvial valleys: some theoretical results

P.Y, Bard

12. Seismic vulnerability and seismic intensity $H$. Sand

13. Analysis of the influence of local soil conditions upon maximum accelerations based on data from 1979 Montenegro earthquake K. Talaganov, D. Aleksovski, V. Gadza

14. On analytical and numerical techniques for seismic analysis of topographic irregularities A. Castellani, A. Peano, L. Sardella

15. On the influence of subsoil water's level fluctuation on the spectral characteristics of the ground V.A. Barzam

16. On the reasons of an increase in the effects of seismic forces on structures on soft soils L.A. Kogan

17. Behaviour of shell send under cyclic loading Application to dynamic response analysis of an earth

J. Biarez, F. Keime, M. Haghgou, J.E. Kyrgeorgiou

18. Guideline-oriented seismic input studies for embedded Strueture W. Langer, E.G. Prate

19. Effect of complex soil ond geological conditions on design of building in seismic regions S.N. Klepikov, A.S. Wyneberg, I.V. Matveyev

20. Surface rupture and eecondary effecte related to the arthquakes of February-March 1981 iv rne Eaotepv

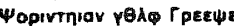
$G$. Koukis

21. Geotechnical aspects of the ground disturbed in the afflicted area by the prent arthquakes within the Eastern Corinthisn gulf Groece G. Koukis

SESSION 2.5: LIQUEFACTION PHENOMENA

1. Simplified procedures for ssessing seiemic liquefection of cands and applications to seismic design of highwey bridges T. Iwasaki, K. Tokida, T. Kimata

2. Design guidelines for liquefection relsted effects in the Northern Aegean basin Dr. C. Soydemir, Dr. Y. Ozkan

3. Pore pressure genertition in enisotropically consolidated sands K. Özaydin, A. Erguvanli, A. Askar 
SESSION 2.6.: SOIL STRUCTURE INTERACTION

1. Approximate analysis of seismic response for mbedded foundation subjected to travelling seismic

M. Iguchi

2. Analysis of dynamic structure-soll-structure interaction problems by 8 continuum mods Dr. W. Rücker

3. Nonlinesr uplift response of soil-structure interaction oystem considering dynemical ground compliance T. Kobori, S. Setogawa, T. Hisatoku, T. Nagase

4. Vibration of besms on distributed springs considering up-lith Y. Hangai, H. Ohmori

5. Experimental and numerical investigerions of the dynsmic oarth pressure S.A. Savidis, H. Klapperich, W. Sarfeld, R. Schuppe

6. A hybrid soil-structure interaction model M. Kostov, H. Boncheva

7. Soil structure interaction effect in buildings constructed in large panel systems D. Jurukovski, Lj. Taskov

8. Multiple-support base excitation of structures A.A. Dumanoglu, R.T. Severn

9. Earthfill dam-foundation dynamic interaction problems S.G. Shulman, A.P. Troitsky

10. Dynamic earth pressures: remarks on experimental results and calculations J. Kyrgeorgiou

11. About static and dynamic soil-structure interaction during earthquake motions Al. Negoita, N. Ungureanu, C. Ionescu, L. Strat

12. A study of seismic effect on structures with regard to loading rate and structure-to-ground interaction E.E. Khachian, V.A. Ambartsumian, A.T. Goroyan

13. Some experimental investigstions regarding the effects of dynamic interaction between overground structure and foundation soil

G. Palämaru, P. Cosmulescu

14. Seismic response of building - foundation systems in layersed soils

B.C. Rajanna, Munirudrappa

SESSION 2.7.: PILE FOUNDATION

1. Pile foundetions under intense earthquake loadings S.A. Anagnostopoulos

2. Stress-strained state and load bearing capacity of pile foundations in clay soil during earthquakes O.I. Ponomarev, A.M. Silkin, I.A. Berezin

3. A study of unilateral soil-pile interaction under dynamic lateral loading

A. Liolios, St. Tsotsos

SESSION 3.: MASS CONSTRUCTION OF DWELLING HOUSES

1. Dynamic behaviour of a skeleton system for mass housing

S.P. Gupta, D.P. Singh

2. Monolithic house-building in Moldavis

S.S. Grafov, Yu. V. Ismailov

\section{SESSION 4.: RESISTANCE OF STRUCTURES}

\section{SESSION 4.1.: EARTHOUAKE RESPONSE AND} RESPONSE SPECTRA

1. Duetlity spectra and collapse spectro for earthqueke resistant structure: Dan Chen

2. Inelastic spectre of some earthquakes recorded in Yugoslavis Matej Fischinger, Peter Fajfar

3. Inelastic response spectrs for the Bucherest accolerogram of March, 4th, 1977 Dr. D.R. Constantinescu, D.V. Dimitriu

4. Duetility requirements for flexibly supported antiseismic structures Prof. F.P. Müller. E. Keintze

5. Reconsideration of the expression of ascillation caused by an earthquake in the case of the elementery elestic ascillator

S. Moraru, loan Sora

6. Damege parameters for bilinear single degree of freedom systems

Bahman Lashkari-Irvani, Prof. helmut Krawinkler
7. Inelastic response spectra for multidegree-of-êreedom shear structures G. Beolchini, G. Rega, F. Vestron

8. Strong motion records obtained during Montensgro, April 15, 1979, earthquake

N. Nauamovski, S. Stamatovska, V. Zelenovic D. Petrovski

9. Some remarks on structural response under arthquakes Al. Baratta, P. Margiotta

10. Nonstationary seismic input and response A. DA Arrigo, M. Di Paola

11. Spectra of structural states and their use in seismic response analysis

I. Eisenberg. T. Abakhanov, O. Tsitsilashvil

12. Analog method for engineering-seismimetric dete processing

G.V. Mamayeva, A.M. Kakhanovsky. E.B. Egorov

13. Esrthquake response of plene frames exhibiting degrading hysteretic capacity

M. Aristodemo, R. Casciaro. A. Vulcano

14. Evaluation of the Corinth strong motion records of Fobruary 24 and 25,1981

P.G. Carydis, J.C. Drakopoulos, J.M. Taflambas

SESSION 4.2.: SEISMIC BEHAVIOUR OF STRUCTURAL SYSTEMS.

1. Montenegro, Yougosiavia, 1979. Earthquake-structura behaviour of Uleinj shopping contro Ivo Podhorsky

2. A comparison of dynamic properties of buildings obtained from numerical analyses and full-scale test Peter Fajfar, Matjaz Godec

3. Earthquake behavior of reinforced concrete frame-wall structurie Prof. Mehdi Saiidi, K.E. Hodson

4. Effect of the structure parameters on the formation of seismic load

T.N. Chachava, G.G. Abashidze, P.A. Rekvava

5. Investigation of seismoresistant mulistoroy box-unit dwellings

IE Itskov, V.A. Shapilov

6. Vibratests of the full-scale building G.A. Shapiro, Y.A. Simon G.N. Ashkinadze, V.F. Zakharov, Y.V. Barkov

7. Experimental determination of force-displacement dependence for ectusl buildings with reinforcod concrete losd-bearing walls G.N. Ashkinadze, J.G. Shenkarenko, O.M. Shogenov

8. Study of the performance of frameless monolithic buildings under seismic ffects L Martynova

9. Theoretical and experimental investigatione of building nonlinear response under the effects of seismic type G.S. Chanukvadze, M.A. Marjanishvili, L.M. Marjanishvili, N.A. Edisherashvili, A.L. Bagmanian

10. Structural ductility in reinforced concrete building stiffened by crose brace criteria for dimensional optimization

G. Zingone, M. Papia, G. Russo

11. Frame-well interaction of multi-story structures at ultimate states

Y. Tanaka Y. Kaneko, M. Mizutani

12. Forced vibration of multi-storey frames having periodically changing rigidities along the height Nahit Kumbasar

13. Comparative analysis of the response of som reinforced concrete structures subjiected to surface and deep monoshock earthquakes D. Capatina, D. Giurgea

14. An experimental. study on the seismic behavior of a brick building model and isolated wall specimens with $R / C$ tie columns

Z. De-Teng, D. Jing-Chen, W. Xi-Nan, Y. Run-Tao, L. Xing-Xiang

15. Analytical investigation of the earthquake behavior of an eight-storey building frame, designed according to the Greek code Andreas J. Kappos

16. Identification of structures with joint rotation J.S. Dimsdale, H.D. McNiven
17. Full-scale dynamic tests of buildings of different structural schemes A.M. Kurzanov, I.N. Burgman

18. Investigation into non-stationary behaviour of structure with non-linear characteristics and random parametera under random loads B. Kirikov

19. Reduction of seismic response of system with changing rigidity using the vibration absorber V.S. Polyakov

20. An experimental study of seismic resistance of framed and largepanel reinforced structures S.G. Shahinian, E.E. Khachian, V.A. Stepanian, M.G. Melkumian

21. The behaviour of Eastern churches in earthquakes Ramiro Sofronie

A study of the earthquake response of sawtooth typ industrial buildings in China Xue Zhen-Dong

23. Dynamic characterization of existing buildings based on experimental measurments C.S. Oliveira, E.C. Carvalho, J. Jervis Pereir

24. Ambient vibration measurements of undamaged and seismically damaged buildings P.G. Carydis, C.P. Mouzakis

SESSION 4.3.: STRUCTURAL ANALYSIS AND DESIGN FOR SEISMIC ACTIONS.

1. The influence of fiexibility of thoor sebe on the losding of verticul alomorts of high risendinge Janez Duhovnik

2. Invertigation of the multi-input-oretem response under seismic excitetion M. Kostov, S. Simeonov

3. Point of view about the enalyas concepte of the structure eubjected to erthquatee G. Sandulescu, G. Cristea

4. The effect of various 3-D seismie-input directions on inslastic building systems bssed on INRESB-3D-82 computer program F.Y. Cheng, J.A. Volker

5. An improved simplified procedure for seismic design of low rise building P.J. Cevallos-Candau

6. Soirmic analysis of irrogular buidinge G.R. Aranda, O.A. Rascón, O.J. Diaz

7. The probsbilistic method for determining the occentricity produced by live lowe in buildinge F. Focardi, E. Manzini

8. A aimplified approsch to the veritication of simple struetures subject to ground motions H. Sand

9. Combined plestic and spetial deformation structura constructione and ground foundetion during arthquake

S.G. Napetvaridze, R.V. Dvalishvili, D.K. Ukieba

10. On consideration of damping in mic asciliwtions of stuctures A.I. Tseitlin

11. Earthquake resistance of structure se space systoms N.A. Nikolayenko, Y.P. Nazarov, AT. Shtoh

12. Seismic rosponse combination of thigh frequency modes M.P. Singh

13. A network model for the nonlinee dynamic analysis of structures

P. Papadopoulos

14. Some aspects concerning the structural design of onestorey industrial halls subjected to seismic action, having the structure made of reinforced and prestressed concrete unit M. Dabija, O. Manoiu

15. Considerations concering a new dynamic behaviour model of multistory buildings to seismic actions S. Moraru, I. Sora

16. The analysis of the influence of the vertical loads on the seismic response of frame type structures Dr. R. Marinov

17. Analysis of the structural systems under seismic effects

T. Kozhuharov, I. Paskaleva, S. Sachanski

18. Dynamic analysis of complete building structures Dr. Yusuf Hatay Onen, M.S. Tomac

19. Consideration of the time dependence of masses and of non-seismic loading in aseismic design H. Sand 
20. Evaluation of understrength and overstress coefficients in R.C. buildings V. Kalevras

21. Reducing overstress probability in existing R.C. structures V. Kalevras

22. Stability of frames to vertical stationary ergodic gaussian esrthquakes G. Muscolino, G. Zingone

23. Analysis of R.C. frameworks under seismic effect fo predetermined elasto-plastic ultimate condition and failure mechanism Bela Csák

24. Modelling of building structures behavior under seismic loading with use an algebraic manipulation system

G. Brankov, M. Spiridonova, K. Ishtev, P. Philipov

25. Approximate analysis of coupled non-linear shear walls Prof. O.A. Pekau

26. Aproximate methods for analysis of constructions subjected to seismic action M. Mironescu, A. Bortnowschi, G. Bratu

27. Inelastic response of prestressed cable networks subjected to multicomponent earthquakes E.A. Uzgider, A.R. Cakit

28. The seirmic design of ductile concrete frames in $\mathrm{N}$. Zealand Thomas Paulay

29. Modified solution of the nonlinear seismic response of framed gystems Emíliá Juhásová

30. Dynamic response of buildings to ground rotation A.M. Awad, J.L. Humar

31. The Air Now Zealand hangar for 747 boeing aircraft Auckland Now Zealand

J.P. Hollings

32. Energy formulation for Nowmerik's stop-by-step procedure in numerical dynemic response analysis K. Washib, E. Tachibana

33. Optimum seismic design of mid-rise buildinge Charles Scawthorn

34. Optimal response anslysis of multy-storey frame structures under seismic excitetion L.S. Kilimnik, K.A. Tonoyan

35. Optimization of seismic risk besing on generalized model of seismic actions A.M. Zharov, M.V. Fedyakov. E.l. Gerasimova

36. Spatial finite element method in entiseismic designs of constructions

J.I. Nemtchinov, A.V. Frolov. A.A. Kozi

37. An evaluation of pseudo-drnamic tang H.M. Aktan, H.M. VanSchieveen

38. Live losds combination factor in seismic situation A. Giuffre, R. Giannin

39. Six dof earthquake simulator the National Technical University of Athens P. Carydis, J. Aristizabal, R. Pulkrabek

40. Astructural model for the stric and dinamic analysis of building space frames D. Bairaktaris

41. Shear wall modeling aiming of the reliability improvement of the Gresk asmic design method D. Bairaktaris

SESSION 4.4.: SEISMIC BEHAVIOUR OF R.C. STRUCTURAL ELEMENTS.

1. Response of RC column horizontal bi-directional deflection history K. Takiguchi, M. Kimura, T. Okamoto

2. Reinforced concrete for seismic structures N. Krapchanski, G. Apostolov

3. Influences of high rate deformation on the fracture of structures during severe earthquakes Jin-ichi Takeda, H. Tachikawa

4. Effect of base rotation and up-lifting of shear walls on aseismic capability of $\mathrm{R} / \mathrm{C}$ frame-wall structures Dr. K. Baba

5. In-plane seismic characteristics evaluation of shes walls with opening S. Wong, M. Saiid

6. Aseismic design criteria correlating strength, stifines and ductility of simple reinforced concrete structures D.R. Constantinescu, T. Postelnicu

7. Practical calculation of plastic moments in eccentrically loaded columns using diagrams F. Wolovits

8. Local bond stress-slip relationships of deformed bars under generalized excitations R. Eligehausen, E.P. Popov, V.V. Bertero
9. New design criteria for concrete structural walls flexure and shear O. Hernández-Basilio

10. The postelastic behaviour of reinforced concrete columns subjected to central force plus reversed bending moment

I. Tertea, T. Onet, L. Sziget

11. Dynamic behaviour and seismic upgrading of reinforced concrete public housing building A. Vignoli, G. Augusti, A. Chiarugi

12. Function of lintsis in ductile behaviour of coupled shear walls A. Cholewicki

13. Seismic response of reinforced concrate frames Ashok K. Jain

14. Numerical prediction of plane R.C. frame response under static and dynamic loading J. Ozbolt, N. Bicanic

15. Anslysis of reinforced concrete beam-column joint under seismic losdin M.N. Fardis, S.S. Liu

16. Mothod of seismic fragility for R.C. frames F. Casciati, L. Faravelli, D. Veneziano

17. Experimental investigation of strength and deformation of reinforced concrete structural walls B. Simeonov

18. Hysteretic behavior of reinforcing deformed hooked bars in $R / C$ joints

R. Eligehausen, V.V. Bertero, E.P. Popov

19. Hysteretic behavior of deformed reinforcing bars under seismic excitations

V. Ciampi, R. Eligehausen, V. Bertero, E. Popov

20. Determining the ultimste state of structural element I. Paskaleva, S. Sachanski, T. Kozhuharov

21. The shear strength of short $R C$ columns H. Umehara, J.O. Jirsa

22. An experimental study on the elasto-plestic behaviour of reinforced concrete frames under reversed cyclic losding

Z. Yicun, T. Jiahua, R. Fudon

23. Inelastic modalling of reinforced concrete section T.K. Santhanam. G. Shanmugam

24. Earthquake response of reinforced concrete frame structures S.G. Arzoumanidis

25. A method for the torional analysis of perforated core Walls 1.1. Sungur

26. Analytical model for cyclic deterioretion of R/C imterior beam-column joints F.C. Filippou, E.P. Popov, V.V. Bertero

27. Hysteretic bohaviour of reinforced conerete mambers (beams and columns) subjected to high shear P. Gavrilovic

28. Investigation of multistorey building reinforced concrete cores under lateral losding A.O. Sahakian

29. Strength in inclined sections of reinforced concrete columns of lightweight concrete with volcanic slage exposed to soismic losd Y.S. Kulygin, I.Z. Batsanadze

30. Aseismic constructions made of reinforced concrete with ceramic stones 1. Rochlin

31. Behaviour of reinforced-concrete frame of industrial multi-storey buildings under the action of seismic losd T.Z. Zhunusov, Y.G. Shakhnovitch, A.D. Azhibekov, B.F. Vasiliev, A.Y Klebanov

32. Inelastic behaviour of reinforced-concrete frame of industrial single-storey building under dynamic excitation of high level T.Z. Zhunusov; M.U. Ashimbayev

33. Strength, stiffness and ductility requirements for coupled walls

M. Saatcioglu, R. Parmelee
SESSION 4.5.: SEISMIC BEHAVIOUR OF STEEL STRUCTURAL ELEMENTS.

Problems of elasto-plastic vibration of thin steel wobs in structural elements Pavol Juhás, Emilia Juhásová

2. Deformation capacity and ultimate strength of cold formed steel members and frames Prof T Ono

3. Low cycle fatigue damage of weak-beam type steal structures due to earthquakes

K. Kaneta, I. Kohzu, H. Miyakawa

4. Mathematical model formulation of a single bay steel frame structure using parametre system identification and shaking table experiments D. Jurukovski, D. Mamucevski

5. New constructive forms of steel earthquake-resistant frames G.M. Ostrikov, Y.S. Maksimov

6. Inelastic behaviour of steel frames subjected to strong earthquakes

V. Petrini, P. Setti, R. Zandonini

SESSION 4.6.: SEISMIC BEHAVIOUR OF MASONRY WALL

Modelling of brick masonry

C. Alongi, A. Casteliani, M. A. Paris

2. Load transfer mechanism and resistance capabilities of composite masonry walls S.C. Anand, D.T. Young

\section{Prestressed masonry} O.H. Basilio

4. Testing of tall slender reinforced concrete and reinforced mesonry walls subjected to vertical and lateral loads J.E. Amrhein, L.G. Seina, R.S. McLean

5. Optimum strength distribution of arthquake resistan coupled structural walls P. Mueller, J.M. Becker

6. Shear strength of brick-mortar couplets J.G. Chinwah

7. Industrial construction of atone buildings with improved seismic stability T.V. Ismailov, A.A. Chuprin

8. Experimental studies on post-tentioned masonry H. Alper, E. Hacim, S. Aysoy

SESSION 4.7.: SEISMIC ISOLATION.

An experimental study on the non-finear behavior of rubber isolators under dynamic losding

P. Srinivasulu, N. Lakshmanan, T.S. Thandavamurthy, K. Muthumani

2. Structures effeciency of seismic insulation of building investigation

A.N. Tetior, V.G Surguchov

3. Experimental and analytical responses of isoleted structures

M. Wakabayashi, T. Fujiwara. T. Nakamura, T. Basoto

4. Some consideration to earthquake isolation structures

A. Negoita, M. Budesc

5. Base isolation of asymmetric buildings: proliminary parametric study A. Rutenberg, M. Eisenterger

6. Dynamic response of bese-isoleted building J. Petrovski, V. Simovski

7. On the earthquake isolation of the buildings Olariu, A. Pocanschi, F. Olariu, A. Pomonis

8. Energy absorbing restrainere for aseismic base isolation

M. Budescu, Al. Negoita

SESSION 5.: COST-BENEFIT ANALYSIS IN EARTHOUAKE ENGINEERING.

Structural and nonstructural damage related to building quality H. Tiedemann

2. Interactive, optimization - based dedign of seismically loaded structures

R.J. Balling, V. Ciampi, K.S. Pister

3. Cost-benefit analysis of earthquake protective measures in residential buildings in the Georgian

Sh.A. Djabua, A.Kh. Koridze

4. A data base scheme for economic evaluation of earthquake effects C.V. Vaidynathan

5. Damage evaluation using reliability indices R. Del Tosto, G.C. Hart, R.E. Englekirk 
SESSION 6.: DESIGN AND CONSTRUCTION OF REINFORCED CONCRETE PRECAS BUILDINGS IN SEISMIC REGIONS.

1. A degrading stiffiness model for precast concrete cladding

H. Palsson, B.J. Goodno

2. Performance of wet horizontal joints and simple shae walls in precast concrete large panel buildings under earthquake loading

H.G. Harris, B.E. Abboud, G.J.J. Wang

3. Precast panel shear walls local damage O.A. Pekau

4. Some aspects related to multistory industrial buildings with precast reinforced concrete frames subjected to seismic action

M. Dabija, R. Giurgea

5. The dynamic properties of the prefabricated posttentioned slabcolumn system Xu Wei, Qi Kuifen, Jiang Jingkai

6. Static and dynamic analysis of a prefabricated large panel system M. Zamolo, I. Podhorsky

7. Seismic qualificatin tests on a large bearing wall prefabricated building

F. Angotti, A. Castoldi, P. Pezzoli, L. Sanpaolesi

8. Construction eystem and structural behaviour of a now procast roinforced concrats structure Y. Sonobe, H. Imai, M. Murakami, N. Niwa, T. Kuchinomachi, S. Arakawa. K. Uesu

9. Hysteretic behaviour of three-storey models of large panel precast structural systems P. Garvrilovic, M. Velkov

10. Reserch for improvement of the stability of large panel structural aystems for soiamic excitation M. Velkov. P. Gavrilovic

11. Shesring etrength in largo-panel buildings joints V.I. Lishak

12. construction of industrial house buildings in aismic hazard regions of Transcaucseia O.G. Tukhareli

13. Mase construction of framing-panel dwelling public and industrital buildings in exismic regions of the U.S.S.R.

V.G. Kornilov, A.M. Kimberg, M.A. Bediashvili, T.M. Janjgava, E.A. Gorodetski, T.K. Janashia, T.A. Katsadze

14. Seismic and dynamic behaviour of two types of reinforced concrete beam-column space subsesemblegas for partial procast multistory industria buildings C. Mihai, R. Giurgea, D. Amariei, L. Tanasachi, G.A. Palamaru

15. Dynamic analysis of large panel buildings with seismic cores D. Diaconu, D. Vasilescu, M. Iticovici, I. Soroceanu, T Dull

16. R.C. procast penels' connections under cyclic actions T.P. Tassios, S.G. Tsoukantas

SESSION 7.: RURAL HOUSES IN EARTHQUAKE AREAS.

1. Seismic risk mitigstion of rursi houses using performanco coefficients selection E.S. Georgescu

2. Experimental investigation and aseismic safety ovelustion of brick masonry buildinge with $\mathrm{R} / \mathrm{C}$ tie columns

L. Xihui, Z. Hongxi, L. Jingwei, L. Liquan

3. Aseismic performance of rural arth buildings in

Chins's northwest region

Gong Si-li, Cao Shao-Kang, Han Meng

4. Dynamic and static experimental analysis of stone masonry building

D. Benedetti, A. Castold

5. On the problem of the optimal seismo-equipment of industrial rural structures A.I. Martemianov

6. Evaluation of the safety level of existing buildings with particular reference, to seismic actions

F. Zaupa, C. Modena, S. Odorizzi

7. Seismic response on earthquake buildings in Greece P. Carydis
SESSION 8.: DAMAGE EVALUATION OF PAST EARTHQUAKES

1. The earthquake in Southern Italy of $\mathbf{2 3}$ November, 1980 , Engineering aspects and interpretation of building damage W. Ammann, B. Pozzo

2. Behaviour of reinforcad concrete buildings during the Southern Italy earthquake of November 23, 1980 Hojjat Ade

3. On the performance of reinforced concrete buildings during the El Asnam earthquake of October 10, 1980 Hojjat Adeli

4. Ghaenat (Khorasan, Iran) earthquake of November 14, 1979 Hojjat Adeli

5. Analysis of the behaviour of two reinforced-concrete buildings during the 1979 Montenegro earthquake Peter Fajfar

6. A survey of damages due to earthquake of July 29 in Western Nepal, India border region S.P. Gupta

7. Damage assessment and ground motion in the Italian earthquake of $23 / 11 / 80$ A.W. Coburn, R.E. Hughes, D.F.T. Nash, R.J.S. Spence

8. Geotechnical engineering aspects of the Southern Italian earthquake of November 23, 1980 E. Berger, J. Studer

9. Some results of a statistical analysis of Friuli records R.L. Grossmayer, R. Fritze

10. Romanian earthquake of March 4, 1977, some specific engineering aspects Mihail Ifrim

11. survey of structursl dameges csused by the Southern lealy earthquake of November 1980 M. Aristodemo, G. Sarà, A. Vulcano

12. Damages to Platees and Erythres due to the FobruaryMarch 1981, Alkyonides gulf (Greoce) earthquakes K. Pitilakis, S. Tsotsos, T. Hatzigogos

13. Acropolis' monuments behaviour during the February 23, 1981 arthquake Kostas Zabas

14. Geotechnical ffects of recent strong Greek corthquakess J. Protonotarios

15. case study for the analytical reproduction of the domage morphology topographical method C.A. Syrmakezis, S. Magalios

SESSION 9.: REPAIRING AND STRENGTHENING OF STRUCTURES AND MONUMENTS.

1. Tall building dynamic property improvemen G. Apostolov

2. Uhtrior strengthening of reinforced concrete fremoworks demaged in earthquakss B. Csák, L. Havady, Gy. Visnovitz

3. Earthquake strenthoning of historical monuments in Dubrovnik, Yugoslavia Drazen Anicic

4. Experimentsl evalustion of strenthening methods on low cost masonry houses for seismic actions Oscar Hernández-Basilio

5. Earthquake resistant strengthening of brick atructures Niu Zezhen

6. The strengthening of stone-masonry buildings for revitslization in seismic regions M. Tomazevic, P. Sheppard

7. Repair and strengthening of reinforced concrete structures after soismic damage G. Augusti, M. Matteuzzi

8. Repsir of structural walls W.G. Corley, A.E. Fiorato, R.G. Oesterle

9. The mechanics of column repsir with reinforced concrete jacket T.P. Tassios

10. Behaviour study on the structure of a big hospital in Bucharest that withstood the strong earthquakes of November the 10 th 1940 and of March the 4th 1977 and on the reinforcement works brought to its structure S. Tologea

11. Restoration and reinforcement of large-pane earthquake damaged buildings in Gasli by opoxy polymer mortars

A.I. Martemyanov, E.P. Alexandryan, V.V. Shirin

12. Reinstating old buildings in an earthquake-prone environment D.G. Cox
13. Incorporated steel structures: A repair/strenthening technique

M.P. Chronopoc.os

14. Seismic behaviour of RC beam-column subassemblages: First results of a co-ordinated experimental research on repair techniques experimental research on repair

15. A contribution to the determination of seismic forces acting on freely supported, articulated ancient buildings

Kostas Zabas

SESSION 10.: SEISMIC RISK ANALYSIS OF SPECIAL STRUCTURES

SESSION 10.1.: NUCLEAR POWER PLANTS

1. Steel energy absorbing restrainers and their incorporation into nuclear power plants for enhanced seismic safety

S.F. Stiemer, Wm. G. Godde

2. A simulation study of the Armenian nuclear power station for seismic resistance

A.G. Nazarov, P.O. Amasian, S.S. Darbinian,

V.L. Mnatsakanian

3. Seismic problems for possible installation of nuclear power plants in Greece

J. Protonotarios

SESSION 10.2.: DAMS AND RELATED STRUCTURES

1. The design of the hydreulic structures situated in seismic areas

2. Coupled dynamic response anslysis of arch dam reservoir systems B. Nath, S.G. Potamitis

3 Seismic interaction analysis of control towers ombodded in ombankment dams G.J. Bureau. T. Udaka

4. Dynamic behaviour of arch dams R. Flesch, M. Eiselmayer

5. Boundary solution and finite element methods in the earthquake response anslysis of dem-water-foundation interaction system

A. Vulpe V. Poterasu, A. Carausu

6. Dynamic characteristice of elestic earth gtructures determined from a seminalytical method B. Martinez, J. Villarreal

7. Experimental studies on large dams by means of massuring ambient vibration

T. Zorapapel, A. Moroianu, D. Radulescu, M. Costea

8. The relationship between dynamic properties and stres state of soil in estimating oarthill dam seismic stabiligy

N.D. ID. Krasnikov, L.A. Eisler

9. Influence of water on earthquake stability of dams and pressure tunnels

T.L. Gvelessiani, J.N. Kylasonia, G.J. Jinjikhashvili, G.P. Mamradze

10. Study of seismic stability of concrete dems P.A. Gutidze, G.K. Ninidze

11. Study of frequencies and shepes of natural vibretions of coocrete dams on generalized elestic foundation N.S. Motsonelidz

SESSION 10.3.: BRIDGES

1. Seismic analysis of a multispan railway bridge: A caso study P. Gülkan, M. Erdik, N. Akkaş, C. Yilmaz, M. Öner

2. The response of a bridge to strong ground shaking R. Shepherd, L. Lisiecki

3. Earthquake resistant cable-stayed bridge system Ramiro Sofronie

4. Seismic design of bridges in high activity region A. Casteglioni, C. Urbano, B. Stupazzini

SESSION 10.4.: TANKS AND COOLING TOWERS

1. Parameters for seismic response analysis of cooling towers

Z. Bittnar, O. Fischer, E. Juhásová

2. Hydrodynamic forces in liquid storage tanks during seismic excitation T. Balendra

3. Bucklign in seismic response of cylindrical liquid storage tanks A. Niwa, R.W. Clough

4. Experimental investigation of a cylindrical tank under earthquake loading

G.C. Manos, R.W. Clough, F. Cambra, G. Hua

5. Some data on seismic response of large capacity tanks placed on the ground

D. Diaconu, S Marinescu, M. Iticovici, S. Ilie 
SESSION 10.5.: MISCELLANEOUS STAUCTURES.

1. Specific dynamic consideration concerning the behaviour of a T.V. - tower to earthquake and wind action

T. Popp, R. Popescu

2. Dynamic interaction of offshore elastic cylindrical shell tanks during horizontal and vertical earthquake excitations

Y. Tanaka, T. Hamamoto, H. Hanakura

3. Shaking table study of a tubular offshore plattorm frame

Y. Ghanaat, R.W. Clough

4. Aseismic design of sprinkler system bearing structure of water cooling towers

H. Kapsarov

5. Seismic risk evaluation of electricel power facilities Julius Solnes 